\title{
Jak zaprojektować kreatywną lekcję?
}

DOI: $10.47050 / 65591876.118-132$

Marlena Plebańska

Niniejszy rozdział przedstawia charakterystykę realizacji kreatywnych zajęć dydaktycznych. Przedstawiono w nim cechy charakterystyczne kreatywnych zajęć dydaktycznych, innowacyjne metody i formy prowadzenia lekcji, a także propozycje planowania kreatywnych lekcji oraz korzyści wynikające z ich realizacji.

Słowa kluczowe:

kreatywność

kompetencje przyszłości

kreatywne lekcje 


\section{How to design a creative lesson?}

DOI: 10.47050/65591876.118-132

Marlena Plebańska

This article presents the characteristics of the implementation of creative didactic classes. The article presents the characteristics of creative didactic classes, innovative methods and forms of lessons. In addition, proposals for planning creative lessons and the benefits of their implementation have been presented.

Keywords:

creativity

future competences

creative lessons 


\section{Wprowadzenie}

Nie ma jednej ogólnie przyjętej definicji kreatywności, w literaturze można znaleźć ich kilkadziesiąt, ponieważ ten z pozoru prosty proces jest bardzo szeroko omawiany i przedstawiany z różnych perspektyw. Najogólniej możemy określić kreatywność jako zdolność tworzenia czegoś nowego, np. nowego rozwiązania, nowego produktu, nowego procesu, nowych pomysłów, niekonwencjonalnych idei czy koncepcji.

Kreatywność jako zdolność do tworzenia nowych rozwiązań charakteryzują cztery podstawowe cechy zdefiniowane przez National Advisory Committee on Creative and Cultural Education (NACCCE):

$\rightarrow$ kreatywność wymaga wykorzystania wyobraźni;

$\rightarrow$ kreatywne działanie jest działaniem celowym, skierowanym na osiągnięcie rezultatu;

$\rightarrow$ efektem kreatywnego działania jest oryginalne dzieło;

$\rightarrow$ efekt powinien być wartościowy z perspektywy założonych celów.

Jak widać, kreatywność jest zatem pojęciem subiektywnym, zależnym od wielu warunków brzegowych wyznaczających ramy kreatywności w danym kontekście. Zachowanie, produkt, idea zostaną uznane za kreatywne w wyniku subiektywnej oceny uprzednio określonych przez jednostkę lub instytucję warunków brzegowych kreatywności oraz celów stawianych przed danym kreatywnym rozwiązaniem.

Kreatywność od dziesięcioleci podlega wielu badaniom, również cechy i postawy osób kreatywnych zostały gruntownie przebadane. Kim zatem jest osoba kreatywna? Jan Fazlagić $(2018$, s. 1) definiuje następujące cechy osób kreatywnych:

$\rightarrow$ wykazują cechy płci przeciwnej-mężczyźni o cechach psychiki kobiecej, kobiety o cechach psychiki męskiej;

$\rightarrow$ są jednocześnie konserwatywne w poglądach i buntownicze;

$\rightarrow$ wykazują pasję wobec swojej pracy, a jednocześnie potrafią na nią spojrzeć z dystansu;

$\rightarrow$ cechują się introwertyzmem i ekstrawertyzmem - potrzebą samotności połączonej z potrzebą bycia wśród ludzi;

$\rightarrow$ wykazują skromność, a zarazem dumę - boleśnie odczuwają zaniżone poczucie własnej wartości i jednocześnie są bardzo pewne siebie;

$\rightarrow$ charakteryzują się zrównoważonym sposobem myślenia, w którym aktywność wykazuje zarówno prawa, jak i lewa półkula; 
$\rightarrow$ odznaczają się dużą dozą energii fizycznej naprzemiennie z silną potrzebą ciszy i spokoju;

$\rightarrow$ wich zachowaniu obserwujemy wiele sprzeczności-połącznie mądrości i dziecinności.

Przedstawiony powyżej wykaz cech osób kreatywnych burzy wiele mitów związanych z kreatywnością, byciem kreatywnym, tworzeniem kreatywnych rozwiązań. Stawia również pytania: jak rozwijać kreatywność? Jak pomagać ludziom kreatywnym rozwijać się? Jak konstruować kreatywne zajęcia dydaktyczne i kreatywne lekcje? Czy dobór odpowiednich metod, form oraz narzędzi prowadzenia zajęć dydaktycznych wpłynie na kreatywność uczniów? Próbę odpowiedzi na te pytania stanowi niniejszy rozdział.

\section{Kogo potrzebuje współczesny świat?}

Żyjemy w czasach, w których w zasadzie jedyną stałością jest permanentna zmiana. Dotyczy ona każdego obszaru naszego codziennego życia. Postępująca robotyzacja i automatyzacja pracy zmienia katalog profesji i zawodów, w których już w niedalekiej przyszłości będziemy pracować. Ciągły rozwój każdego człowieka wpisany jest już na stałe w indywidualne ścieżki kariery niezależnie od wykonywanego zawodu, a tempo rozwoju zawodowego nieprzerwanie wzrasta. Jeszcze kilka lat temu wystarczający był systematyczny rozwój w ramach jednej profesji zgodny z koncepcją LLL (lifelong learning). Obecnie to za mało, współczesny człowiek coraz częściej będzie musiał zmieniać zawód kilka razy w ciągu swojego życia. Z kolei postępująca nowoczesność z jednej strony oraz zniszczenia planety, globalne ocieplenie, bieda i głód z drugiej wymuszają na współczesnym człowieku, by był kreatywny. Świat potrzebuje bowiem teraz ludzi twórczych, otwartych na zmianę, potrafiących aktywnie z niej korzystać w kontekście realizacji celów indywidualnych i grupowych. Współczesny świat potrzebuje ludzi przełamujących schematy i stereotypy, potrafiących myśleć w sposób niestandardowy, łączyć $w$ toku realizacji podejmowanych przez siebie działań wiedzę i umiejętności z różnych dziedzin. Współczesny świat potrzebuje ludzi kreatywnych potrafiących tworzyć nowe rozwiązania w każdym aspekcie życia. Kreatywność powinna być zatem rozwijana już od najmłodszych lat, w szkole, a nawet w przedszkolu. Powinna zostać na stałe wpisana w programy i scenariusze zajęć, a także $w$ działania i kompetencje nauczycieli. 


\section{Dlaczego lekcja powinna być kreatywna?}

Trudno wymienić wszystkich "wrogów” edukacji, a ich identyfikacja zależy w dużej mierze od roli i perspektywy osób rozpoznających ich w środowisku szkolnym. Z perspektywy ucznia jednymi z kluczowych wrogów edukacji są nuda i brak zaangażowania w proces dydaktyczny. Ich główną przyczynę stanowi niewłaściwy sposób prowadzenia lekcji, najczęściej jako lekcji podawczych skoncentrowanych na przekazaniu wiedzy, a nie na rozwoju indywidualnych talentów uczniów. Edukacja, aby odpowiedzieć na potrzeby zmieniającego się świata, wymaga znaczących zmian praktycznie w każdym jej aspekcie. Jedną z kluczowych modyfikacji jest zmiana form, metod i narzędzi prowadzenia zajęć dydaktycznych, tak aby odpowiadały one potrzebom kształcenia kompetencji przyszłości. Lekcja przygotowująca współczesnego ucznia do życia w realnym społeczeństwie to lekcja dająca mu przestrzeń do poznawania i eksperymentowania, zdobywania twórczych doświadczeń, poszukiwania i rozwijania własnych talentów. Zajęcia ukierunkowane na rozwój szeroko rozumianej kreatywności to droga do wyposażenia uczniów w kompetencje, które pozwolą im nie tylko na aktywne funkcjonowanie w zmianie, ale też na aktywne kreowanie zmiany w każdym aspekcie ich dorosłego życia.

\section{Plan kreatywnej lekcji}

Bardzo trudno jednoznacznie zdefiniować, czym jest kreatywna lekcja. Czy jest to lekcja prowadzona w taki sposób, aby kształcić kompetencje przyszłości, czy może, aby pobudzić kreatywność uczniów? Czy raczej jest to lekcja prowadzona w kreatywny sposób przez kreatywnych nauczycieli? W zasadzie każda z przedstawionych powyżej propozycji wydaje się słuszna, a wariantów kreatywnych lekcji istnieje dużo więcej. Kiedy mówimy o kreatywnej lekcji, definiujemy ją bardzo różnie. Określenie jej jednoznacznego przebiegu, stałego procesu czy cyklu nie jest możliwe, ponieważ nie sposób jednoznacznie określić jej następujących parametrów:

$\rightarrow$ cele kreatywnej lekcji - określane indywidualnie dla każdej lekcji;

$\rightarrow$ metody dydaktyczne - wybierane indywidualnie dla każdej kreatywnej lekcji w kontekście uprzednio ustalonych celów lekcji;

$\rightarrow$ narzędzia pracy-wykorzystywane do przeprowadzenia kreatywnej lekcji, wyznaczane indywidualnie w kontekście indywidualnych celów i metod przyjętych dla danej kreatywnej lekcji; 
$\rightarrow$ wybór przestrzeni dydaktycznej, w której odbywa się kreatywna lekcja - adaptowana osobno dla każdej lekcji prowadzonej w ramach zajęć szkolnych lub przestrzeń pozaszkolna, np. park, muzeum, centrum handlowe etc. dobrane do potrzeb kreatywnej lekcji;

$\rightarrow$ czas realizacji kreatywnej lekcji - każdorazowo obliczany w zależności od celu; kreatywna lekcja może trwać przyjęte 45 minut lub dowolną wielokrotność tego czasu; może też odbywać się w trybie ciągłym lub stanowić cykl zajęć;

$\rightarrow$ podział na etapy kreatywnej lekcji, który przyjmować może różne formy; do najczęściej definiowanych należą:

$\rightarrow$ etap przygotowawczy, etap realizacji, etap podsumowania;

$\rightarrow$ etap organizacyjny, etap przygotowawczy, etap realizacji, etap podsumowania.

Rysunek 1. przedstawia przykładowy podział kreatywnej lekcji na etapy.

Rysunek 1. Podział kreatywnej lekcji na etapy

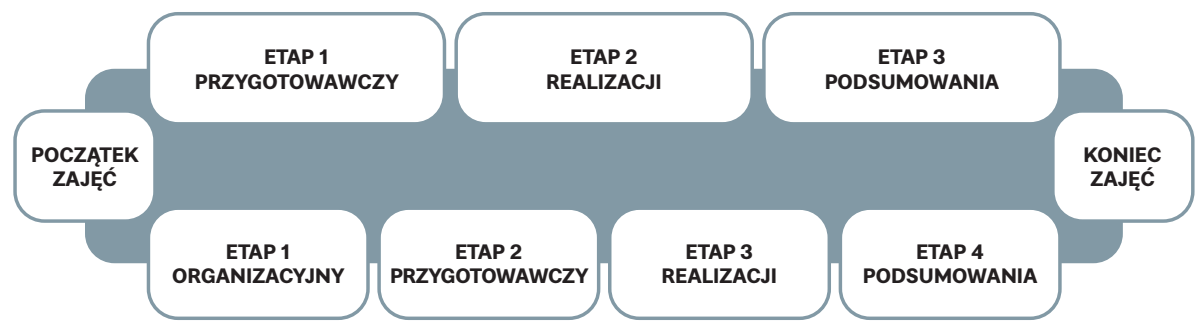

Źródło: opracowanie własne.

Przedstawiony podział kreatywnej lekcji to tylko najczęściej wybierany sposób realizacji kreatywnych zajęć. Mogą one przebiegać w innych, dowolnych etapach, które zależą od autorskiego pomysłu nauczyciela. Są one definiowane dla każdej kreatywnej lekcji oddzielnie, bowiem każda z nich ma przebieg indywidualny, wynikający ze specyfiki przedstawionych parametrów, które należy uwzględnić, a w szczególności celów dydaktycznych lekcji. 
Jednak niezależnie od liczby etapów, na które zostanie podzielona lekcja, podczas przygotowywania, a potem prowadzenia zajęć definiuje się te same trzy podstawowe elementy każdego etapu: cele etapu, zadania dla danego etapu oraz oczekiwane efekty każdego z nich.

Podstawowe elementy każdego etapu kreatywnej lekcji definiuje się następująco:

$\rightarrow$ cele etapu - określenie celów danego etapu lekcji;

$\rightarrow$ zadania etapu - określenie zadań danego etapu oraz sposobu ich realizacji;

$\rightarrow$ efekty-określenie oczekiwanych efektów danego etapu.

Niezależnie od ostatecznego podziału kreatywnej lekcji na etapy i elementy etapów wspólna jest konieczność zdefiniowania brzegowych parametrów i składowych dla kreatywnej lekcji. Brak definicji tych parametrów i składowych może spowodować, że kreatywna lekcja nie będzie tak efektywna, jak mogłaby być w wybranych obszarach, lub nie zrealizuje przyjętych celów całościowo. Sprecyzowanie dokładnych działań na każdym etapie, dokładny oraz celowy dobór metod i narzędzi spowodują, że zadania realizowane na każdym z etapów kreatywnej lekcji będą prowadziły do uzyskania założonych efektów dydaktycznych. Dlatego też, aby zapewnić zaplanowanie wszystkich kluczowych parametrów i składowych lekcji, warto opisać kreatywną lekcję choćby w sposób uproszczony, porządkujący najważniejsze zagadnienia związane z planowaniem, realizacją i ewaluacją cyfrowej lekcji, takie jak:

$\rightarrow$ definicja,

$\rightarrow$ cele,

$\rightarrow$ przewidywany czas realizacji,

$\rightarrow$ kreatywne metody dydaktyczne,

$\rightarrow$ narzędzia dydaktyczne,

$\rightarrow$ przestrzeń dydaktyczna,

$\rightarrow$ niezbędne kompetencje nauczycieli,

$\rightarrow$ konieczne wejściowe kompetencje uczniów.

Zastosowanie opisu kreatywnej lekcji przyczyni się do zapewnienia jej właściwej organizacji oraz do efektywnej realizacji procesu dydaktycznego w ramach prowadzenia twórczych działań podczas kreatywnej lekcji. Jeżeli jednak autorzy kreatywnych lekcji chcieliby stworzyć 
ich kompletny opis, wówczas warto rozważyć stworzenie scenariusza kreatywnej lekcji.

\section{Scenariusz kreatywnej lekcji}

Podobnie jak w przypadku samego zdefiniowania kreatywnej lekcji, nie istnieje gotowy model opracowywania scenariuszy kreatywnej lekcji. Scenariusze kreatywnych lekcji, podobnie jak same kreatywne lekcje, przybierają bardzo różnorodne postacie i są zapisywane w rozmaitych formach. Bardzo istotne pozostaje jednak opracowanie scenariusza kreatywnej lekcji tak, aby opisywał jej podstawowe założenia brzegowe. Do głównych z nich możemy zaliczyć:

$\rightarrow$ tytuł zajęć - wskazujący na treści merytoryczne lekcji,

$\rightarrow$ cele lekcji-główne i szczegółowe cele lekcji,

$\rightarrow$ poziom edukacyjny zajęć - określenie poziomu edukacyjnego uczniów, dla których przeznaczona jest lekcja,

$\rightarrow$ specyfika grupy docelowej-określenie kompetencji wejściowych uczniów, którzy będą uczestniczyć w danej lekcji,

$\rightarrow$ zakres merytoryczny - określenie zakresu merytorycznego zajęć,

$\rightarrow$ założenia czasowe - określenie ramy czasowej zajęć i czasu realizacji poszczególnych etapów lekcji,

$\rightarrow$ wykorzystywane metody i narzędzia realizacji zajęć - określenie metod i narzędzi realizacji lekcji,

$\rightarrow$ wykorzystywane zasoby edukacyjne - określenie niezbędnych zasobów edukacyjnych wykorzystywanych w toku lekcji,

$\rightarrow$ przebieg zajęć - określenie przebiegu realizacji zajęć ze szczególnym uwzględnieniem przyjętych kreatywnych metod pracy,

$\rightarrow$ ewaluacja zajęć - określenie sposobu oraz narzędzi ewaluacji zajęć.

Realizując scenariusz kreatywnej lekcji, można skorzystać z gotowych wzorców scenariusza kreatywnej lekcji lub zaprojektować swój własny. Coraz częściej szkoły projektują autorskie scenariusze zajęć, które oczywiście podlegają modyfikacji i są stale rozwijane. Nauczyciele, korzystając z jednolitego scenariusza kreatywnych lekcji na poziomie szkoły, tworzą bazę wiedzy scenariuszy zarówno przedmiotowych, jak i interdyscyplinarnych. Na rysunku 2 zaprezentowano sześć podstawowych kroków realizacji scenariusza kreatywnej lekcji. 
Rysunek 2. Sześć kroków realizacji scenariusza kreatywnej lekcji

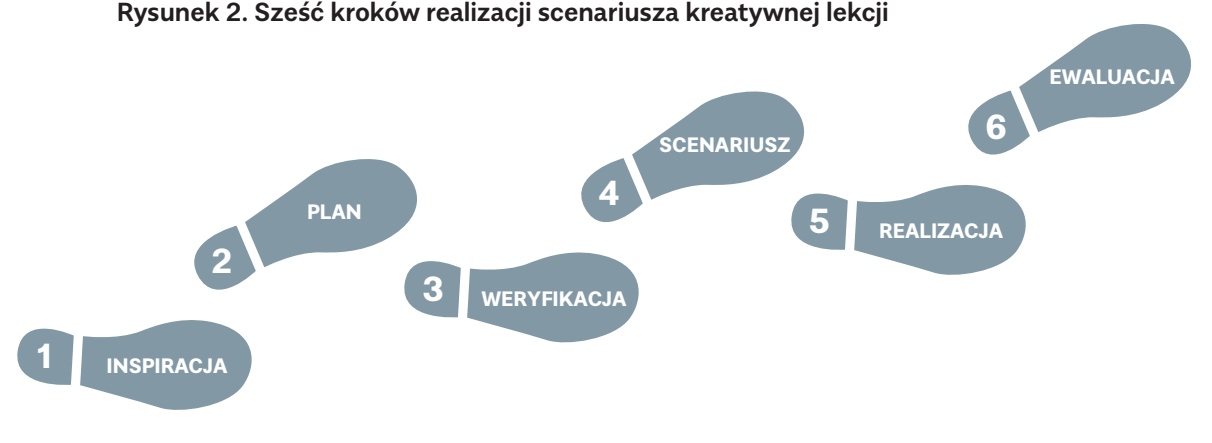

Źródło: opracowanie własne

1. Inspiracja - etap zbierania inspiracji, doświadczeń, pomysłów na projekt autorskich zajęć. Do najczęściej realizowanych aktywności na tym etapie należą: udział w otwartych kreatywnych lekcjach realizowanych przez doświadczone placówki, udział w warsztatach i szkoleniach przygotowujących do pracy z wykorzystaniem kreatywnych metod pracy oraz z wykorzystaniem narzędzi edukacyjnych ukierunkowanych na kreatywność, dzielenie się doświadczeniami z osobami mającymi praktykę w realizacji kreatywnych zajęć. Często pomysł na kreatywną lekcję rodzi się przypadkiem, na marginesie innych działań dydaktycznych.

2. Plan - etap precyzowania pomysłu na kreatywną lekcję, określania zakresu merytorycznego lekcji oraz metod i narzędzi realizacji lekcji. Określa się cele dydaktyczne lekcji, które determinują metody i narzędzia wykorzystane podczas lekcji.

3. Weryfikacja - etap weryfikacji pomysłu na kreatywną lekcję. Analizuje się możliwości wdrożenia pomysłu oraz związane z jego realizacją zarówno szanse, jak i zagrożenia przeprowadzenia kreatywnej lekcji.

4. Scenariusz - etap opracowywania scenariusza, kiedy określa się dokładny zakres działań dydaktycznych, które będą prowadzone w ramach kreatywnej lekcji, ze szczególnym uwzględnieniem kreatywnych form pracy. Scenariusze kreatywnych lekcji bardzo często są opracowywane przez grono osób. W przypadku realizacji scenariuszy przez osoby indywidualne scenariusze bardzo często poddaje się pod dyskusję w szerszym gronie lub ocenie koleżeńskiej.

5. Realizacja - etap pierwszego wdrożenia zajęć kreatywnych, pierwszej realizacji zajęć z uczniami, kiedy najczęściej pojawiają się jeszcze 
kwestie wymagające dopracowania lub zmiany. Zwykle po pierwszej realizacji zajęć modyfikowane są kwestie wymagające korekt, tak aby ostateczny kształt zajęć przyjął postać pozbawioną błędów.

6. Ewaluacja - etap ewaluacji efektywności dydaktycznej kreatywnej lekcji.

\section{Kreatywne metody pracy wykorzystywane w ramach kreatywnych lekcji}

Scenariusz realizacji kreatywnej lekcji powinien uwzględniać wykorzystanie kreatywnych metod pracy oraz kreatywnej pracy zespołowej. Istnieje wiele nowoczesnych, innowacyjnych metod nauczania, którymi można posłużyć się w celu rozwijania u uczniów kreatywności oraz budowania kompetencji przyszłości, wśród których kreatywność jest jedną z kluczowych. Do najbardziej innowacyjnych metod pracy stawiających zarówno na samo stymulowanie kreatywności, jak i na pracę projektową oraz kształcenie kompetencji przyszłości, możemy zaliczyć:

$\rightarrow$ STEAM,

$\rightarrow$ EduSCRUM,

$\rightarrow$ Design thinking.

\section{STEAM}

STEAM jako metoda uczenia się i nauczania skupia się na zaspokojeniu potrzeb gospodarki XXI w. przez rozwijanie kompetencji przyszłości. STEAM stawia na naukę projektową konsolidującą pięć kluczowych bloków tematycznych: naukę, technologię, inżynierię, sztukę i matematykę. Koncepcja ta jest ukierunkowana na kształcenie uczniów, którzy dzięki realizacji projektów potrafią myśleć w sposób innowacyjny i niekonwencjonalny, podejmują rozważne ryzyko, angażują się w eksperymentalne uczenie się i twórcze rozwiązywanie problemów, a także są chętni do współpracy i aktywnie uczestniczą w procesach twórczych. Filozofia STEAM odzwierciedla koncepcję:

STEAM = Science \& Technology interpretowane przez Engineering \& Arts, bazujące na Mathematics

STEAM to idea edukacyjna stworzona w Rhode Island School of Design, która dodała sztukę do wcześniejszej koncepcji STEM. Według tej koncepcji "celem jest wspieranie prawdziwych innowacji łączących 
myślenie naukowca lub technologa z koncepcją artysty lub projektanta". STEAM to naturalne procesy twórcze i poznawcze, angażujące w proces uczenia się wszelkie możliwości ucznia i wszystkie obszary jego mózgu. Tak więc dopiero model STEAM daje możliwość pełnego wykorzystania potencjału uczniów i kształtowania kompetencji przyszłości. STEAM zapewnia możliwość kompleksowego wykształcenia u uczniów szeroko rozumianej przedsiębiorczości i postaw przedsiębiorczych dzięki realizacji następujących postulatów:

$\rightarrow$ STEAM uczy młodych ludzi, w jaki sposób aktywnie zmieniać świat oraz kreować otaczającą nas rzeczywistość, zarówno w życiu prywatnym, jak i społecznym.

$\rightarrow$ STEAM stawia na innowacyjność i kreatywność jako kluczowe wartości, które powinny być rozwijane u każdego pracownika.

$\rightarrow$ STEAM daje uczniom możliwość eksperymentowania i podejmowania twórczego ryzyka na rzecz realizacji innowacyjnych rozwiązań.

$\rightarrow$ STEAM stawia na pracę projektową, w której kluczową rolę odgrywa zespół samozarządzających się uczniów działających w myśl zasad zwinnego zarządzania projektami Agile (Super TEAM), planowania przedsięwzięć projektowych i prowadzenia ich dla osiągnięcia zamierzonych celów.

$\rightarrow$ STEAM to indywidualny rozwój każdego z uczniów poprzez realizacje grupowych projektów ukierunkowanych na rozwój świata oraz umiejętność oceny i identyfikacji własnych mocnych i słabych stron.

$\rightarrow$ STEAM kształtuje postawę przedsiębiorczą. Charakteryzuje się ona inicjatywnością, aktywnością, niezależnością i innowacyjnością w życiu osobistym, społecznym, w tym zawodowym.

$\rightarrow$ STEAM stawia na motywację i determinację w realizowaniu celów osobistych i wspólnych, zarówno prywatnych, jak i społecznych.

$\rightarrow$ STEAM pozwala wybrać te treści, których opłaca się uczyć, oraz weryfikować ich wartość.

$\rightarrow$ STEAM to holistyczny rozwój każdego człowieka sprawdzający się równie dobrze w kształceniu przedszkolaków, jak i seniorów (oraz wszystkich grup pomiędzy).

$\rightarrow$ STEAM pozwala uczniom stać się autorami własnego procesu edukacyjnego, a nie jego biernymi konsumentami, dzięki czemu kreuje się postawy przedsiębiorcze. 
W edukacji skoncentrowanej na kształcenie kompetencji przyszłości potrzebujemy odzwierciedlenia naturalnych procesów poznawczych. Potrzebujemy "otwarcia drzwi" do prawdziwego świata i uwzględnienia naturalnych zasad poznawania w cyklach nauczania i uczenia się. STEAM jest jedną z metod przygotowujących uczniów do nowych realiów rynku pracy.

Koncepcja STEAM stanowi jedną z najwyżej cenionych metod edukacyjnych wprowadzanych do systemów oświaty w wielu krajach świata. Metoda STEAM stawia ucznia w roli badacza, odkrywcy, projektanta i wykonawcy, który wykorzystuje naukę, technologię, inżynierię, sztukę i matematykę do tworzenia własnych rozwiązań, projektów i innowacji. W modelu STEAM uczniowie pracują twórczo, podejmują ryzyko, angażują się w eksperymentalne uczenie się, rozwiązują problemy i współpracują w atmosferze, która zezwala na popełnianie błędów i zachęca do uczenia się na ich podstawie. Nauka w modelu STEAM to rozwijanie indywidualnych talentów każdego z uczniów oraz jednoczesny rozwój kompetencji społecznych, kompetencji cyfrowych i szeroko rozumianych postaw przedsiębiorczych (Plebańska, Trojańska 2018). STEAM sprawdza się w nauczaniu na każdym poziomie edukacyjnym i stanowi doskonały sposób kształcenia niezależnie od tego, jaki zawód w przyszłości wybiorą uczniowie. STEAM rozwija postawy przedsiębiorcze, uczy krytycznego myślenia, rozwiązywania problemów i wielu innych umiejętności, które mogą być używane przez całe życie, niezależnie od profesji, jaką się wykonuje. STEAM to również koncepcja, która pomaga pobudzić kreatywność, rozszerza perspektywę postrzegania świata. STEAM to wreszcie sprawdzona metoda rozwoju osób pracujących nad innowacyjnymi projektami, nowymi produktami i usługami (Plebańska, Trojańska 2018).

\section{Design thinking}

Design thinking to metoda tworzenia innowacyjnych produktów i usług na podstawie dobrze zrozumianych oczekiwań użytkowników. Główne założenia Design thinking to:

$\rightarrow$ koncentracja na użytkowniku - zrozumienie jego uświadomionych i nieuświadomionych potrzeb;

$\rightarrow$ interdyscyplinarny zespół - spojrzenie na problem z wielu perspektyw;

$\rightarrow$ eksperymentowanie i częste testowanie hipotez - budowanie prototypów i zbieranie feedbacku od użytkowników. 
W efekcie zastosowania Design thinking powstają rozwiązania, które:

$\rightarrow$ odpowiadają stawianym celom i potrzebom użytkowników;

$\rightarrow$ są technologicznie wykonalne;

$\rightarrow$ są ekonomicznie uzasadnione.

Design thinking to usystematyzowane podejście do procesu innowacji bardzo powszechnie stosowane w biznesie, lecz równie efektywnie wykorzystywane w edukacji. Pierwszym krokiem we wdrażaniu Design thinking jest zbudowanie interdyscyplinarnego zespołu, w skład którego wchodzą specjaliści z różnych branż, np. inżynierowie, technolodzy, specjaliści od marketingu czy projektowania, socjolodzy etc. W przypadku projektów edukacyjnych podczas budowania interdyscyplinarnego zespołu uczniowie muszą mieć możliwość włączenia do niego osób biegłych w różnych dziedzinach, o zróżnicowanych talentach i zainteresowaniach. W takim zespole uczniowie będą w stanie wszechstronnie i wielopłaszczyznowo przeanalizować problem projektowy.

Następnie powołany zespół realizuje, krok po kroku, kolejne etapy projektu:

$\rightarrow$ empatyzacja,

$\rightarrow$ definiowanie problemu (określenie głównych wytycznych projektowych, analiza danych niezbędnych do zdefiniowania projektu),

$\rightarrow$ tworzenie koncepcji projektu (burza mózgów w zespole projektowym),

$\rightarrow$ modelowanie, prototypowanie rozwiązania,

$\rightarrow$ testy i ewaluacja prototypu,

$\rightarrow$ publikacja i produkcja projektu.

Posługując się zestawem narzędzi i technik Design thinking, pracuje się w taki sposób, aby wypracować rozwiązanie możliwe do wdrożenia. Celem każdego zespołu niezależnie od tematyki projektu jest wygenerowanie innowacyjnego rozwiązania oraz sprawdzenie jego działania na etapie prototypowania. Ścieżka prowadząca przez kolejne etapy nie musi być liniowa. Porażka poniesiona na etapie prototypowania może wymagać powrotu do etapu generowania pomysłów albo nawet definiowania problemu i rozpoczęcia procesu od początku. Design thinking to metoda, która pozwala na popełnianie błędów, stanowią one naturalną część realizacji projektu. To właśnie dzięki analizie błędów, które pojawiły się w projekcie na etapie prototypu, oraz ich stałej modyfikacji dochodzimy do realizacji pożądanego rozwiązania (Plebańska, Trojańska 2018). 


\section{EduSCRUM}

EduSCRUM to idea zaczerpnięta ze świata IT, gdzie SCRUM, wywodzący się z nurtu Agile (zwinne zarządzanie projektami), stanowi zbiór praktyk wprowadzających w środowisko biznesowe wartości takie jak zaangażowanie, odwaga, skupienie, otwartość i poszanowanie. Opiera się on na trzech głównych filarach:

$\rightarrow$ przejrzystość (widoczność wszystkich aspektów danego procesu),

$\rightarrow$ inspekcja (weryfikowanie działania, jego rezultatów),

$\rightarrow$ adaptacja (korekta ewentualnych błędów).

EduSCRUM do świata edukacji został wprowadzony przez Willy'ego Wijnandsa, wieloletniego nauczyciela chemii i fizyki z Holandii. Wijnands, zainspirowany praktyką SCRUM na całym świecie, zaimplementował ją na swoich zajęciach. EduSCRUM to praktyczna i przejrzysta metoda pracy projektowej. Nauczyciel, rozpoczynając projekt, w sposób jasny i zrozumiały dla uczniów przedstawia cele projektowe. Następnie uczniowie samodzielnie, w grupie oraz indywidualnie, sprawdzają, jakie są ich postępy, czego potrzebują do lepszego uczenia się, a co jest im zbędne na danym etapie i co im przeszkadza. Na proces składa się sześć praktyk:

$\rightarrow$ tworzenie zespołu (Team Formation),

$\rightarrow$ planowanie działania (Sprint Planning),

$\rightarrow$ wspólne uzgodnienia (Stand-up),

$\rightarrow$ przegląd działania (Sprint Review),

$\rightarrow$ wgląd w działanie (Retrospective),

$\rightarrow$ wnioski osobiste (Personal Reflection).

W EduSCRUM nauczyciel jest facylitatorem procesu, wspiera swoich uczniów, przestaje być osobą, która przekazuje wiedzę, a staje się partnerem dla ucznia w jej poszukiwaniu. Cały proces uczy skutecznej komunikacji oraz odpowiedzialności za uczenie się. EduSCRUM stanowi wspaniałe narzędzie do pracy z uczniami w każdym wieku, daje nauczycielowi i uczniom dużo wolności, przy równoczesnym zachowaniu uważności na realizowanie programu. Willy Wijnands oraz wielu innych nauczycieli w Europie i poza nią zauważyli, jak wiele EduSCRUM wniósł do ich praktyki, pozwolił zminimalizować czas poświęcony na realizowanie podstawy programowej, wprowadził do szkoły nową kulturę komunikacji, ograniczył czas poświęcony na prace domowe, których 
nie zadaje już nauczyciel, tylko sam uczeń, jeśli czuje, że jest mu potrzebna. EduSCRUM jest zatem doskonałą metodą pracy projektowej w projektach STEAM (Orbitowska 2018).

\section{Podsumowanie - efekty kreatywnych lekcji}

Kreatywne zajęcia często kojarzą się z chaosem, serią działań podejmowanych ad hoc. W rzeczywistości jednak wymagają przemyślanego planu i określonej struktury, która zapewni osiągnięcie założonych celów dydaktycznych. Oczywiście dynamika pracy grupy oraz sam przebieg zajęć determinują nieprzewidziane zmiany, na które każdy nauczyciel powinien być gotowy, jednak to w celowym wykorzystaniu kreatywnych metod i dobrym pomyśle na zajęcia tkwi efektywność lekcji. Kreatywne lekcje cechują się indywidualnym podejściem do uczniów, za każdym razem odmienną strukturą i dynamiką pracy dostosowaną do potrzeb grupy. Kreatywne lekcje to dla uczniów pole do eksperymentowania, które pozwala im na:

$\rightarrow$ zdobywanie kompetencji przyszłości,

$\rightarrow$ poszukiwanie i rozwijanie indywidualnych talentów,

$\rightarrow$ sprawdzanie się w nowych rolach,

$\rightarrow$ współuczestnictwo w innowacyjnych projektach

i wiele innych.

Kreatywne lekcje to pole budowania szeroko rozumianej kreatywności, rozwijanie umiejętności wykorzystywania wyobraźni, ukierunkowanie na celowe działania kreatywne, twórcza realizacja innowacji. 